\title{
Effect of annealing and substrate temperature on structural and optoelectronic properties of a-SiGe:H thin films
}

\author{
M. S. Abo Ghazala ${ }^{1}$, M. M. El-Zaidia ${ }^{1}$, A. H. Ammar ${ }^{2}$ and Ibrahim A. Saleh ${ }^{1}$ \\ ${ }^{1}$ Physics Department, Faculty of Science, Menoufia University, Egypt \\ ${ }^{2}$ Department of Physics, Faculty of Education, Ain Shams University, Roxy, Cairo 11757, Egypt
}

\begin{abstract}
Hydrogenated a- $\mathrm{Si}_{0.47} \mathrm{Ge}_{0.53}$ thin films were prepared at 200 and $250^{\circ} \mathrm{C}$ by the glow-discharge deposition technique from $\mathrm{SiH}_{4}$ and $\mathrm{GeH}_{4}$ gases. The Structural changes of the films were characterized using IR, XRD and SEM after annealing at $300^{\circ} \mathrm{C}$ for $8 \mathrm{~h}$. Remarkable structural degradation was observed upon annealing because of the formation of hydrogen bubbles which give rise to surface bumps. The influence of annealing on the electrical conductivity and optical energy gap of a- $\mathrm{Si}_{0.47} \mathrm{Ge}_{0.53}: \mathrm{H}$ thin films was discussed. The results revealed that the electrical conductivity is increased with increasing the annealing temperatures and /or annealing time, while optical energy gap is decreased. On the other hand it was found that the activation energy of crystallization deduced from the annealing time dependence of the conductivity using Avrami's equation is structural dependent.
\end{abstract}

\section{Keywords: Optical properties, electrical properties, a-SiGe:H, hydrogen content and crystallization.}

\section{NTRODUCTION}

Amorphous silicon and its alloys of Group IV elements, like germanium, have gained importance due to their applications in various photonic devices, e. g., solar cell, photodetector, and light emitting diode. Hydrogenated amorphous silicon - germanium (a- $\mathrm{SiGe:H)}$ are used as a narrow band gap materials for amorphous silicon-based solar cells. High efficiency solar cells are necessary to convert solar energy to electrical energy at low cost. Since the quality of a- $\mathrm{Si}_{1-\mathrm{x}} \mathrm{Ge}_{\mathrm{x}}: \mathrm{H}$ is not as good as that of a-Si:H, some attempts were carried out to improve the optical and electrical properties of $\mathrm{a}-\mathrm{Si}_{1-\mathrm{x}} \mathrm{Ge}_{\mathrm{x}}: \mathrm{H}$ by changing the preparation conditions and by annealing the samples [1-7]. In this study, the effect of annealing temperature on structural, electrical and optical properties of a- $\mathrm{Si}_{0.47} \mathrm{Ge}_{0.53}: \mathrm{H}$ alloys was investigated.

\section{II . EXPERIMENTAL}

Thin films of a- $\mathrm{Si}_{0.47} \mathrm{Ge}_{0.53}: \mathrm{H}$ were prepared by glow-discharge deposition system with capacitively coupled diode reactors from $\mathrm{SiH}_{4}$ and $\mathrm{GeH}_{4}$ plasmas. At a substrate temperature of 200 and $250{ }^{\circ} \mathrm{C}$, a $\mathrm{RF}$ power of $13.6 \mathrm{MHz}$, a RF power of $10 \mathrm{~W}$, a pressure of about 0.18 mbar and a gas flow of $5 \mathrm{sccm}$, a- $\mathrm{Si}_{0.47} \mathrm{Ge}_{0.53}: \mathrm{H}$ thin films were grown on quartz substrates for optoelectronic characterization and on crystalline $\mathrm{Si}$ for composition analysis. Infrared absorption spectra were measured in the range between 400 and $2200 \mathrm{~cm}^{-1}$ using a Nicolet Fourier transform infrared spectrometer ( model 740 ). After base line correction, the IR absorption peaks were fitted by Gaussian to obtain the integrated absorption intensity I*. As the film thickness was usually below $1 \mu \mathrm{m}$, the correction proposed by Langford et al. [8] was employed to obtain the integrated absorption I. The optical band gap $\mathrm{E}_{\mathrm{g}}$ was deduced from transmission and reflection measurements using JASCO V-570 UV-Vis Spectrophotometer-Instructions. The samples were investigated by the scanning electron microscopy ( SEM ) after annealing at $300^{\circ} \mathrm{C}$ for $8 \mathrm{~h}$. For electrical measurements, a co-planer method was used for the dark and photo-conductivity in vacuum. The light source of a tungsten lamp of $100 \mathrm{~mW} / \mathrm{cm}^{2}$ was employed.

\subsection{Infrared Absorption Spectra}

\section{RESULTS AND DISCUSSION}

Figure (1) shows the infrared (IR) absorption spectra of a- $\mathrm{Si}_{0.47} \mathrm{Ge}_{0.53}: \mathrm{H}$ films prepared from $\mathrm{SiH}_{4}$ and $\mathrm{GeH}_{4}$ gases at substrate temperature $\left(\mathrm{T}_{\mathrm{s}}\right) 200$ and $250^{\circ} \mathrm{C}$, respectively. For a-SiGe:H films, the wagging, bending and stretching modes of Si-H and Ge-H bonds occur in the 500-750,750-950 and $1800-2200 \mathrm{~cm}^{-1}$ ranges, respectively. The modes near 2000 and $2100 \mathrm{~cm}^{-1}$ are stretching modes associated with $\mathrm{Si}-\mathrm{H}$ vibrations. The corresponding stretching modes for Ge-H vibrations are at 1880 and $2000 \mathrm{~cm}^{-1}$. The bending modes for Si- $\mathrm{H}_{2}$ vibrations appear near 845 and $890 \mathrm{~cm}^{-1}$, while the corresponding bending modes for $\mathrm{Ge}-\mathrm{H}_{2}$ vibrations appear at 775 and $835 \mathrm{~cm}^{-1}$ [9-11]. 




Figure (1): IR- spectra of a-Si $i_{0.47} \mathrm{Ge}_{0.53}: \mathrm{H}$ prepared at $200^{\circ} \mathrm{C}$ and $250^{\circ} \mathrm{C}$

From figure (1) it is seen that with raising substrate temperature $\left(\mathrm{T}_{\mathrm{s}}\right)$ from 200 to $250^{\circ} \mathrm{C}$, the hydrogen related absorption lines decrease in intensity and the bending modes that are due to dihydride groups $\left(\mathrm{Si}-\mathrm{H}_{2}\right.$ and Ge- $\left.\mathrm{H}_{2}\right)$ appeared at 845 and $890 \mathrm{~cm}^{-1}$ in a highly hydrogenated materials $\left(\mathrm{T}_{\mathrm{s}}=200^{\circ} \mathrm{C}\right)$ disappear while the Si-H stretching mode at $2000 \mathrm{~cm}^{-1}$ increases in intensity relative to the $2100 \mathrm{~cm}^{-1}$ stretching mode and becomes dominant. Also, the $1880 \mathrm{~cm}^{-1}$ stretching mode associated with $\mathrm{Ge}-\mathrm{H}$ vibration in the bulk shows dominance at higher substrate temperature $\left(\mathrm{T}_{\mathrm{s}}=250^{\circ} \mathrm{C}\right)$ while the $\mathrm{Ge}-\mathrm{H}$ stretching mode at $2000 \mathrm{~cm}^{-1}$ disappears [1]. Thus, the formation of microvoides in $\mathrm{a}-\mathrm{Si}_{0.47} \mathrm{Ge}_{0.53}: \mathrm{H}$ alloys is accompanied by a transition of $\mathrm{Si}-\mathrm{H}$ stretching mode from $2000 \mathrm{~cm}^{-1}$ to near $2100 \mathrm{~cm}^{-1}$ and the appearance of the $2000 \mathrm{~cm}^{-1} \mathrm{Ge}-\mathrm{H}$ stretching mode. Accordingly, the $2000 \mathrm{~cm}$ ${ }^{1}$ stretching mode appeared in a- $\mathrm{Si}_{0.47} \mathrm{Ge}_{0.53}: \mathrm{H}$ alloys is associated with vibrations of both $\mathrm{Si}-\mathrm{H}$ bonds in the dielectric medium and hydrogen bound to Ge surfaces [1]. Infrared (IR) absorption spectra of a-Si $\mathrm{Si}_{0.47} \mathrm{Ge}_{0.53}: \mathrm{H}$ thin films prepared at 200 and $250^{\circ} \mathrm{C}$ before and after annealing at $300^{\circ} \mathrm{C}$ for $8 \mathrm{~h}$ are shown in figures (2) and (3), respectively. It is shown that the integrated intensity of the waging, bending and stretching bonds decreases. In the stretching mode range of the wave number, the spectra show that the integrated absorption intensity of Ge-H and $\mathrm{Si}-\mathrm{H}$ stretching bonds is decreasing after annealing at $300^{\circ} \mathrm{C}$ for $8 \mathrm{~h}$. It is seen also that the $2000 \mathrm{~cm}^{-1}$ band increases in intensity relative to the $2100 \mathrm{~cm}^{-1}$ stretching mode indicating that hydrogen moves around in the network and is partially evolved, thus causing a change in the atomic density of the SiGe network. The hydrogen evolved from the films leads to structural relaxation caused by the annealing [4-7].

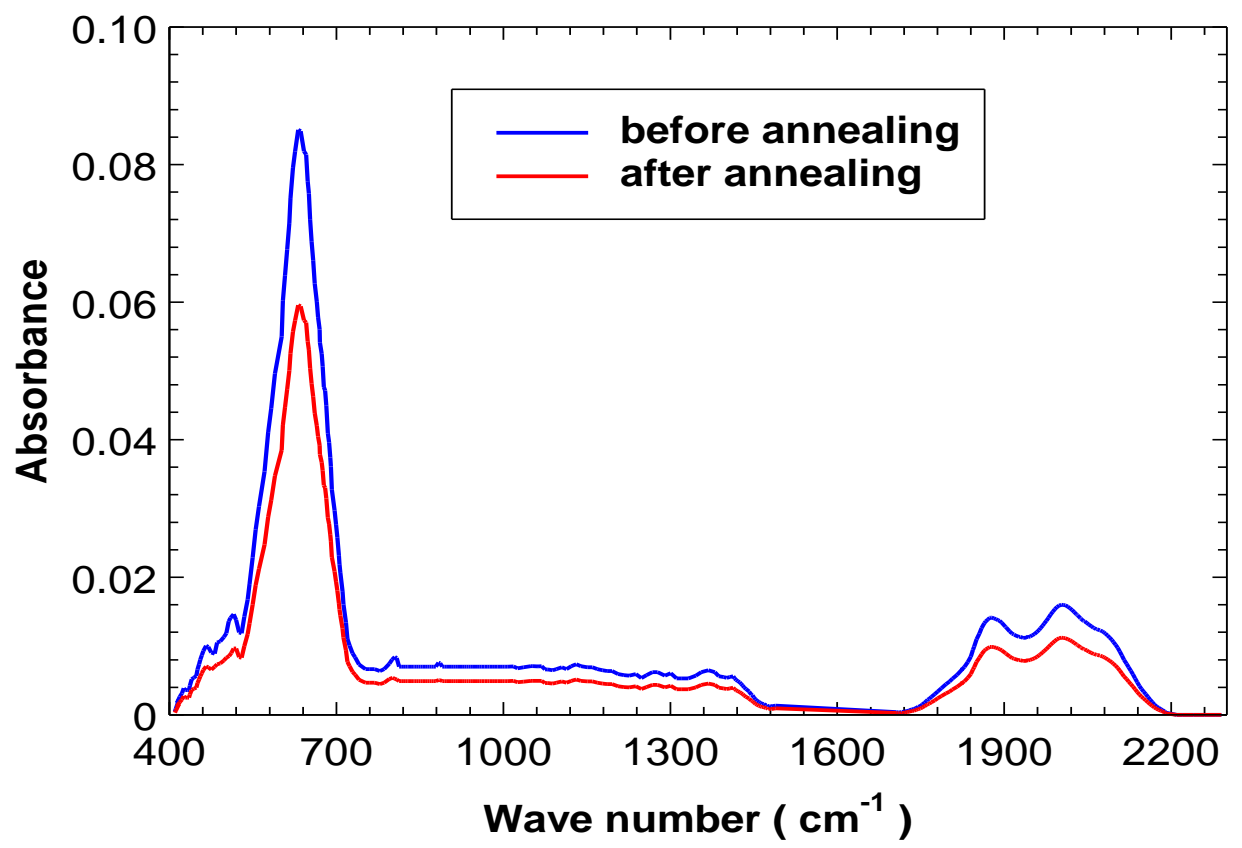

Figure (3): IR- spectra of a- $\mathrm{Si}_{0.47} \mathrm{Ge}_{0.53}: \mathrm{H}$ prepared at $200^{\circ} \mathrm{C}$ before and after annealing at $300^{\circ} \mathrm{C}$. 


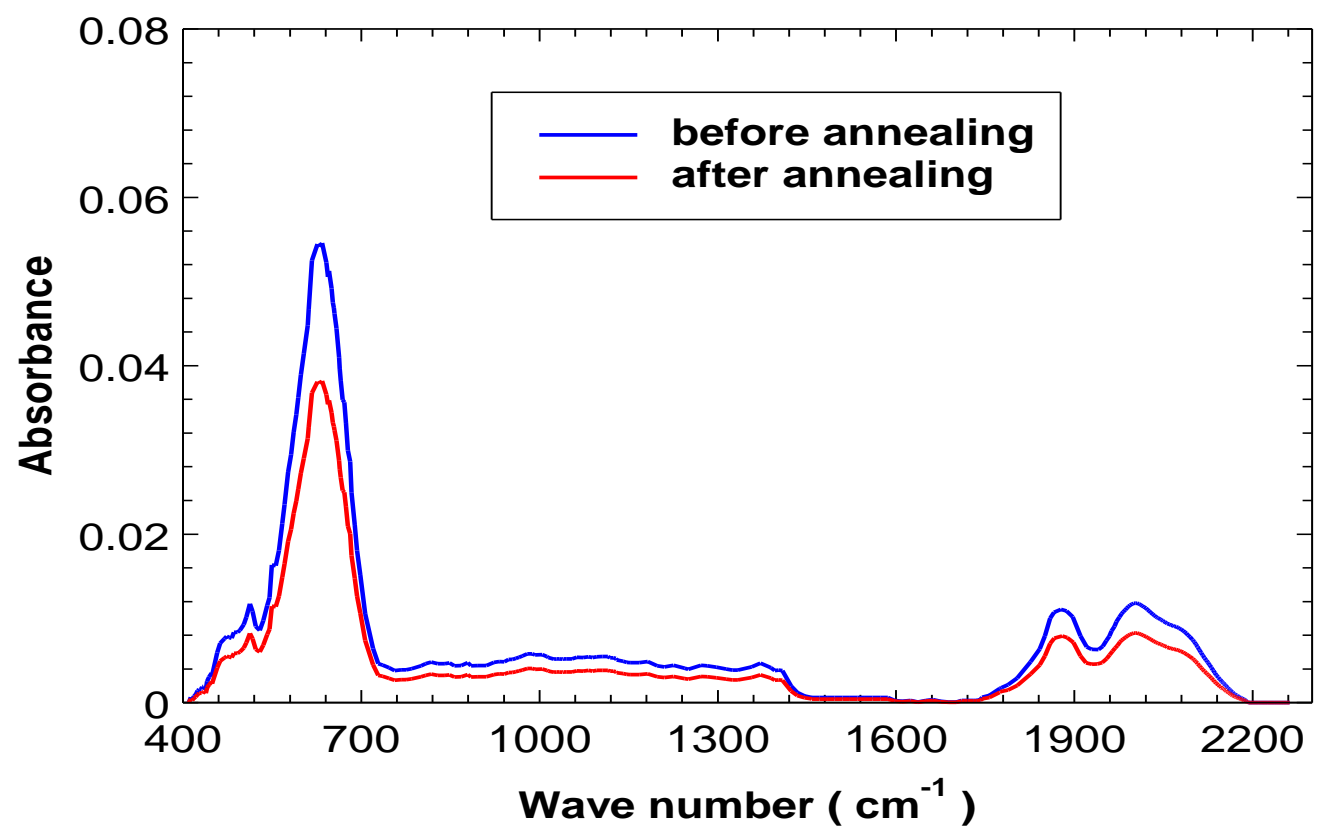

Figure (3) : IR-spectra of a- $\mathrm{Si}_{0.47} \mathrm{Ge}_{0.53}: \mathrm{H}$ prepared at $250^{\circ} \mathrm{C}$ before and after annealing at $300^{\circ} \mathrm{C}$.

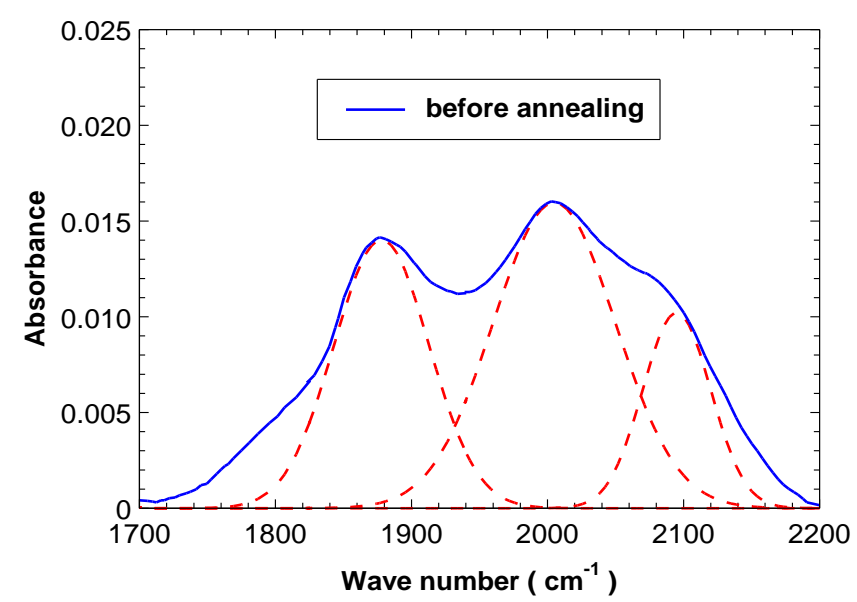

Figure (4): Fitting for IR- spectra in the stretching mode of a-Si $\mathrm{Si}_{0.47} \mathrm{Ge}_{0.53}: \mathrm{H}$ prepared at $200^{\circ} \mathrm{C}$ before annealing.

The hydrogen content $\left(\mathrm{N}_{\mathrm{H}}\right)$ calculated by fitting the stretching mode before and after annealing for samples prepared at $200{ }^{\circ} \mathrm{C}$ and $250^{\circ} \mathrm{C}$ is given in table (1). For brevity see figure (4) of a-SiGe:H prepared at $200{ }^{\circ} \mathrm{C}$ before annealing. The fitting was done by using the Gaussian distribution for calculating the hydrogen content and is written as :

$$
y(x)=\frac{\beta}{\sqrt{2 \pi(x)}} \exp \left(\frac{\left(\omega-\overline{\omega_{0}}\right)^{2}}{2 x^{2}}\right)
$$

Where $\boldsymbol{\beta}, \boldsymbol{\omega}, \overline{\omega_{0}}, \boldsymbol{x}$, are the titration value, the frequency, the peak frequency, also $x=2.35$ FWHM, where (FWHM) is full width of half maximum.

Table (1): Hydrogen content of a- $\mathrm{Si}_{0.47} \mathrm{Ge}_{0.53}: \mathrm{H}$ thin films before and after annealing at $300^{\circ} \mathrm{C}$ for $8 \mathrm{~h}$.

\begin{tabular}{|c|c|c|c|}
\hline The samples & $\mathrm{T}_{\mathrm{s}}\left({ }^{\circ} \mathrm{C}\right)$ & $\begin{array}{c}\text { Hydrogen content }\left(\mathrm{N}_{\mathrm{H}}\right) \mathrm{cm}^{-3} \\
\text { before annealing }\end{array}$ & $\begin{array}{c}\text { Hydrogen content }\left(\mathrm{N}_{\mathrm{H}}\right) \mathrm{cm}^{-3} \\
\text { after annealing }\end{array}$ \\
\hline a-SiG:H & 200 & $3.76 \times 10^{21}$ & $2.63 \times 10^{21}$ \\
\hline a-SiG:H & 250 & $3.00 \times 10^{21}$ & $2.18 \times 10^{21}$ \\
\hline
\end{tabular}


It is seen from table (1) that the total hydrogen content $\left(\mathrm{N}_{\mathrm{H}}\right)$ is decreasing upon annealing due to the evolution of hydrogen from the network.

\subsection{Scanning Electron Microscopy (SEM)}

The samples were investigated by the scanning electron microscopy (SEM) after annealing at $300^{\circ} \mathrm{C}$ for $8 \mathrm{~h}$. Figures (5) and (6) show the SEM images of a-Si ${ }_{0.47} \mathrm{Ge}_{0.53}: \mathrm{H}$ thin films prepared at $200^{\circ} \mathrm{C}$ and $250^{\circ} \mathrm{C}$, respectively. The surface of the films illustrates close bubbles with the hydrogen. The hydrogen forming the bubbles arises from the rupture of the $\mathrm{Si}-\mathrm{H}$ and $\mathrm{Ge}-\mathrm{H}$ bonds activated by the thermal energy of the annealing temperature[13] and by the energy released from the recombination of thermally generated electron hole pairs $[14,15]$.

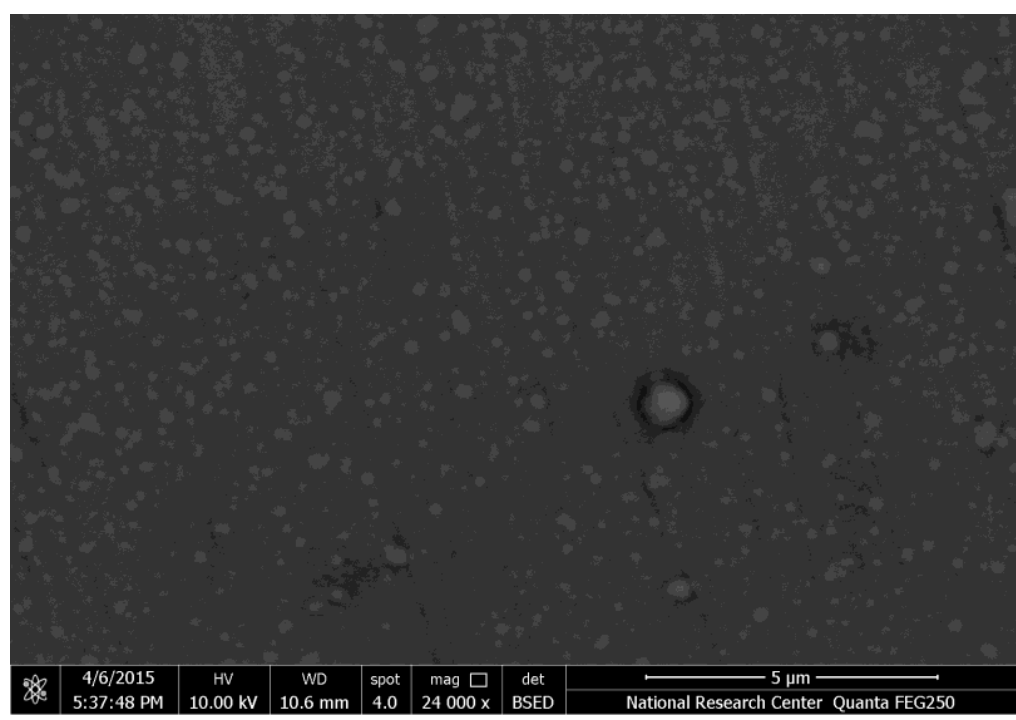

Figure (5): The SEM image of a-Si $i_{0.47} \mathrm{Ge}_{0.53}: \mathrm{H}$ prepared at $200^{\circ} \mathrm{C}$ and annealed at $300{ }^{\circ} \mathrm{C}$ for $8 \mathrm{~h}$.

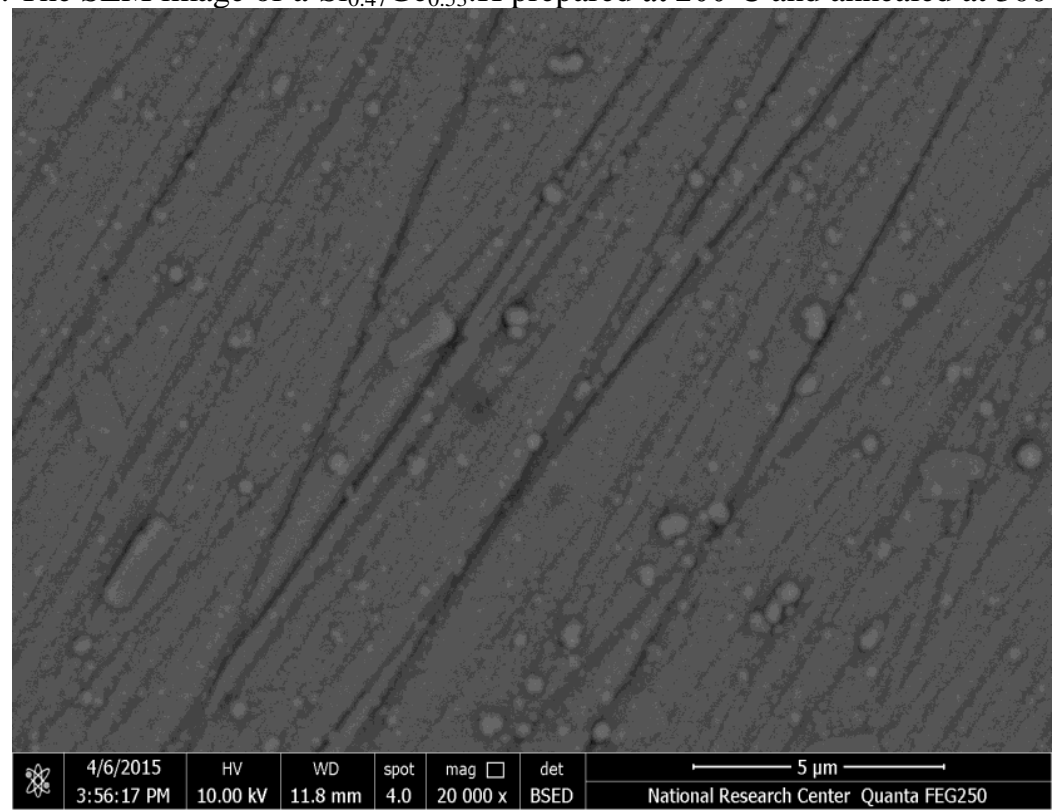

Figure (6): SEM image of a-Si $\mathrm{Si}_{0.47} \mathrm{Ge}_{0.53}: \mathrm{H}$ prepared at $250^{\circ} \mathrm{C}$ and annealed at $300^{\circ} \mathrm{C}$ for $8 \mathrm{~h}$.

\subsection{Optoelectronic data}

The optical band gap is useful material parameter that allows comparison of a-SiGe:H thin films based materials regarding their light absorption properties. Figures (7) and (8) shows the relation between $(\alpha h v)^{1 / 2}$ and $(\mathrm{h} v)$ of $\mathrm{a}_{-\mathrm{Si}_{0.47}} \mathrm{Ge}_{0.53}: \mathrm{H}$ prepared at 200 and $250^{\circ} \mathrm{C}$, respectively. According to Tauc's relation, the optical enegy gaps deduced from the plots are given in tables (2) and (3) for the two samples before and after annealing. 


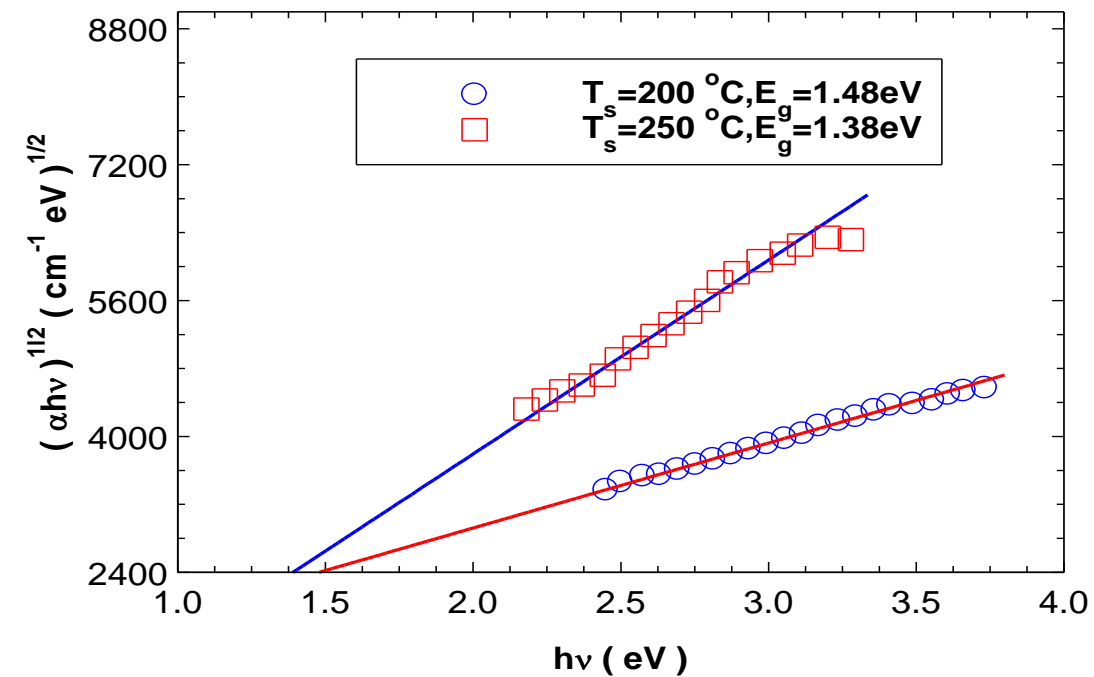

Figure (7) : $(\alpha h v)^{1 / \sqrt{2}}$ vs $h v$ for samples prepared at $200{ }^{\circ} \mathrm{C}$ and $250{ }^{\circ} \mathrm{C}$, before annealing.

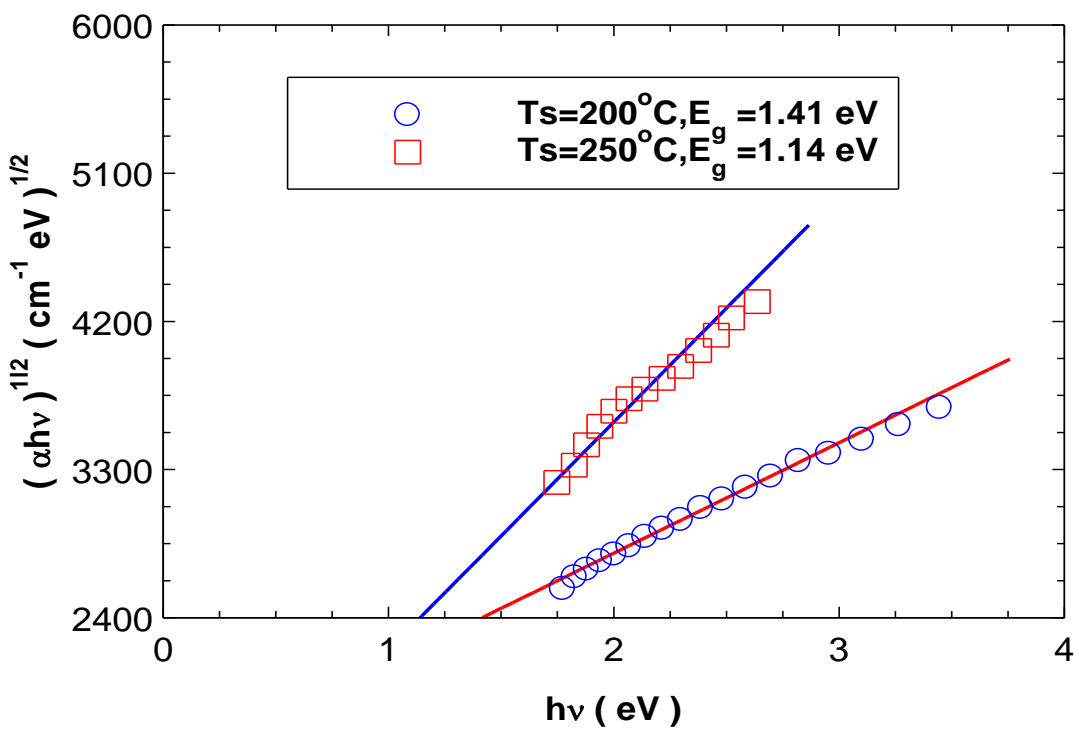

Figure $(8):(\alpha h v)^{1 / \sqrt{2}}$ vs $h v$ of prepared at $200{ }^{\circ} \mathrm{C}$ and $250{ }^{\circ} \mathrm{C}$, after annealing.

The calculated Urbach energy $E_{u}$ for the two samples is also given in tables (2) and (3). The data shows that the optical energy gap is decreased with rising the substrate and/or annealing temperature while the Urbach energy is increased mainly due to the decreased total hydrogen content in agreement with previous works [16$18]$.

Table (2): The data of optical band gap $E_{g}^{0, t}$ and Urbach energy $E_{U}$ before annealing.

\begin{tabular}{|c|c|c|c|c|}
\hline The sample & $\mathrm{T}_{\mathrm{s}}\left({ }^{\circ} \mathrm{C}\right)$ & $\begin{array}{c}\text { Hydrogen content } \\
\left(\mathrm{N}_{\mathrm{H}}\right) \mathrm{cm}^{-3}\end{array}$ & $E_{g}{ }^{0{ }^{25}}(\mathrm{eV})$ & $E_{U}(\mathrm{meV})$ \\
\hline $\mathrm{a}-\mathrm{Si}_{0.47} \mathrm{Ge}_{0.53}: \mathrm{H}$ & 200 & $3.76 \times 10^{21}$ & 1.48 & 68 \\
\hline $\mathrm{a}-\mathrm{Si}_{0.47} \mathrm{Ge}_{0.53}: \mathrm{H}$ & 250 & $3.00 \times 10^{21}$ & 1.38 & 85 \\
\hline
\end{tabular}

Table (3): The data of optical band gap $\mathbb{E}_{g}^{\text {apt }}$ and Urbach energy $E_{U}$ after annealing.

\begin{tabular}{|c|c|c|c|c|}
\hline The sample & $\mathrm{T}_{\mathrm{s}}\left({ }^{\circ} \mathrm{C}\right)$ & $\begin{array}{c}\text { Hydrogen content }\left(\mathrm{N}_{\mathrm{H}}\right) \\
\mathrm{cm}^{-3}\end{array}$ & $E_{g}^{\text {qpt }}(\mathrm{eV})$ & $E_{U}(\mathrm{meV})$ \\
\hline $\mathrm{a}-\mathrm{Si}_{0.47} \mathrm{Ge}_{0.53}: \mathrm{H}$ & 200 & $2.63 \times 10^{21}$ & 1.41 & 93 \\
\hline $\mathrm{a}-\mathrm{Si}_{0.47} \mathrm{Ge}_{0.53}: \mathrm{H}$ & 250 & $2.18 \times 10^{21}$ & 1.14 & 125 \\
\hline
\end{tabular}


The dark and photo- conductivities as a function of temperature for a- $\mathrm{Si}_{0.47} \mathrm{Ge}_{0.53}: \mathrm{H}$ prepared at 200 and $250^{\circ} \mathrm{C}$ in the temperature range 303-423 $\mathrm{K}$ are shown in figures (9) and (10), respectively. It is seen that the relation between the electrical conductivity and the temperature obey Arrhenius type equation:

$$
\sigma=\sigma_{0} \exp \left(-E_{a} / k_{B} T\right)
$$

where $\sigma$ is electrical conductivity, $\mathrm{E}_{\mathrm{a}}$ is the activation energy and $\mathrm{k}_{\mathrm{B}}$ is the Boltzmann's constant. The conductivity measured at $303 \mathrm{~K}$ and the activation energy calculated from the slopes of the lines are given in table (4). It is seen that the electrical conductivity increases and the activation energy decreases by rising the substrate temperature. This is due to the decrease of hydrogen content as shown in table (1).

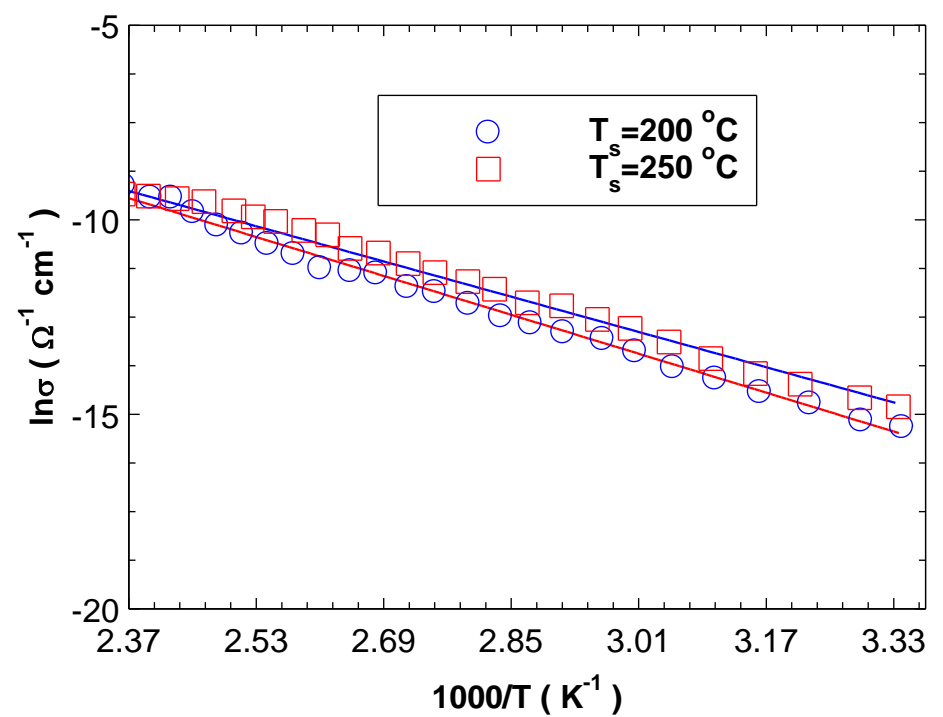

Figure (11): Dark conductivity vs. inverse of the temperature for a- $\mathrm{Si}_{0.47} \mathrm{Ge}_{0.53}: \mathrm{H}$ thin films.

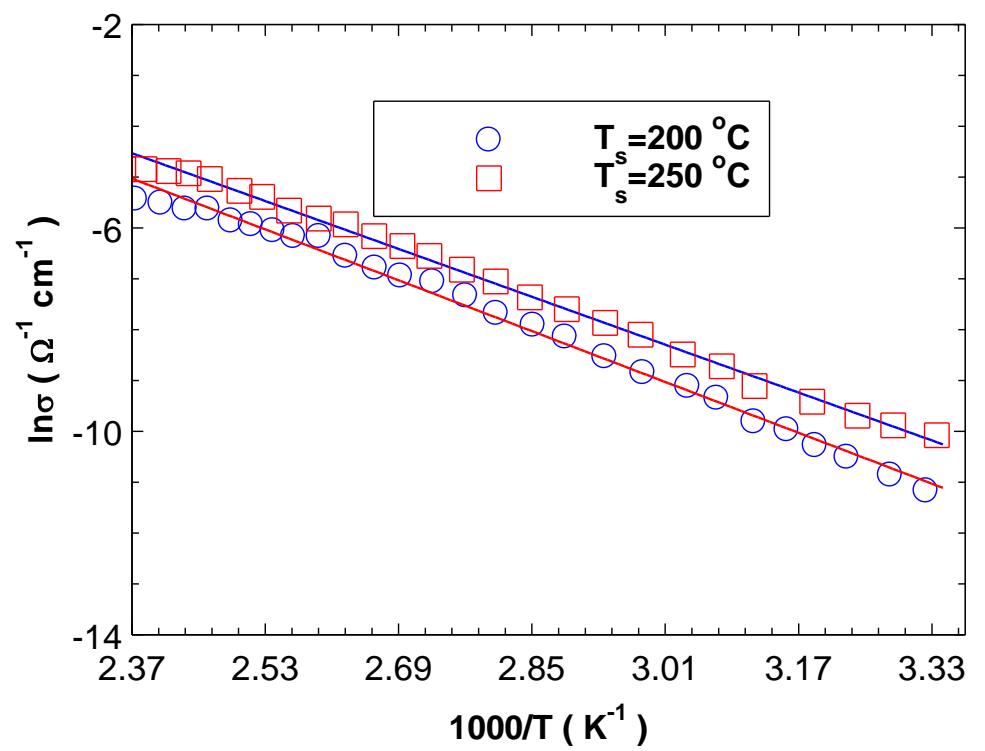

Figure (12) : Photo- conductivity vs. inverse of the temperature for a- $\mathrm{Si}_{0.47} \mathrm{Ge}_{0.53}: \mathrm{H}$ thin films.

Table (4): Dark and photo-conductivity measured at $303 \mathrm{~K}$ and the activation energy of a-Si ${ }_{0.47} \mathrm{Ge}_{0.53}: \mathrm{H}$.

\begin{tabular}{|c|c|c|c|c|c|}
\hline The sample & $\mathrm{T}_{\mathrm{s}}\left({ }^{\circ} \mathrm{C}\right)$ & $\sigma_{\mathrm{d}}\left(\Omega^{-1} \cdot \mathrm{cm}^{-1}\right)$ & $\sigma_{\mathrm{Ph}}\left(\Omega^{-1} \cdot \mathrm{cm}^{-1}\right)$ & $\mathrm{E}_{\mathrm{a}, \mathrm{d}}(\mathrm{eV})$ & $\mathrm{E}_{\mathrm{a}, \mathrm{Ph}}(\mathrm{eV})$ \\
\hline $\mathrm{a}-\mathrm{Si}_{0.47} \mathrm{Ge}_{0.53}: \mathrm{H}$ & 200 & $2.07 \times 10^{-7}$ & $1.80 \times 10^{-5}$ & 0.54 & 0.51 \\
\hline $\mathrm{a}-\mathrm{Si}_{0.47} \mathrm{Ge}_{0.53}: \mathrm{H}$ & 250 & $3.97 \times 10^{-7}$ & $4.72 \times 10^{-5}$ & 0.48 & 0.47 \\
\hline
\end{tabular}

The electrical conductivity of a- $\mathrm{Si}_{0.47} \mathrm{Ge}_{0.53}: \mathrm{H}$ system as a function of annealing times were recorded at different temperatures 493, 523, 553 and $573 \mathrm{~K}$. The results obtained for the two samples as shown in Figure (11), and Figure (12) illustrate that the electrical conductivity increases with increasing the annealing time at 
constant annealing temperature and is attributed to partially to evolution of hydrogen from internal surfaces of voids and partially to crystallization effects depending on the annealing temperature since the crystallization temperature of a-Ge is near $300^{\circ} \mathrm{C}$.

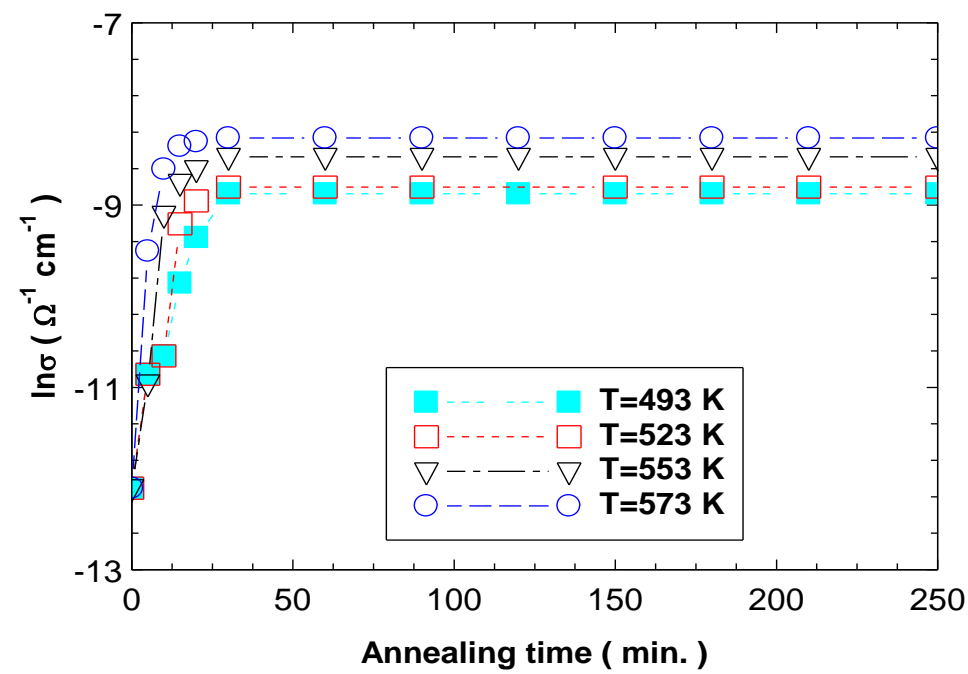

Figure (11): Dark conductivity of a-Si $\mathrm{Si}_{0.47} \mathrm{Ge}_{0.53}: \mathrm{H}$ prepared at $200^{\circ} \mathrm{C}$ Vs. annealing time at constant annealing temperature.

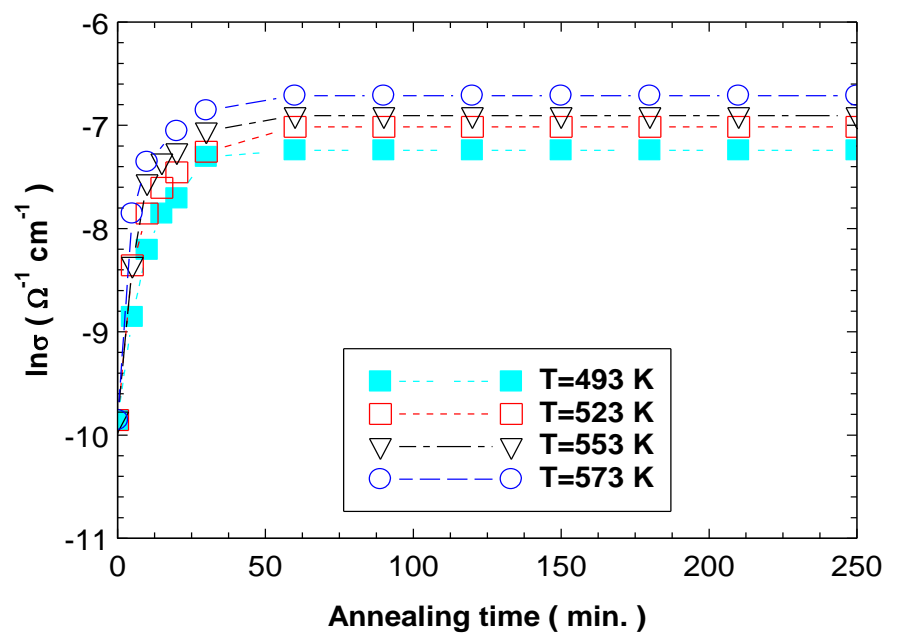

constant Figure (16 ): Dark conductivity of a-Si $0.47 \mathrm{Ge} 0.53: \mathrm{H}$ prepared at $250^{\circ} \mathrm{C}$ Vs. annealing time at annealing temperatures.It is known that the electrical conductivity of the ordered system is higher than that of orphous one and the ordered systems exhibit lower activation energy than the amorphous one [19]. Thus the lectrical conductivity measurements as a function of annealing time at constant temperature are used to study the othermal crystallization kinetics using Johnson-Mehl-Avermi`s (JMA) equation [20] in the form: $\chi=1$ - exp[-

$\left.(\mathrm{kt})^{\mathrm{n}}\right]$

where $\chi$ is the volume fraction of the crystalline phases transformed from the amorphous state at time $\mathrm{t}, \mathrm{n}$ refers to the order of reaction and $\mathrm{k}$ is the effective overall reaction rate, which actually reflects the rate of crystallization $[21,22]$ and is given by:

$$
\mathrm{k}=\mathrm{k}_{\mathrm{o}} \exp \left[-\mathrm{E}_{\mathrm{c}} / \mathrm{RT}\right]
$$

Here $k_{o}$ indicates the number of attempts to over come the energy barrier. From the results of the conductivity as a function of annealing time the volume fraction $\chi$ is calculated from the relation:

$$
\chi=\left(\sigma_{\mathrm{t}}-\sigma_{0}\right) /\left(\sigma_{-} \sigma_{\mathrm{o}}\right)
$$

where $\sigma_{\mathrm{o}}$ is the electrical conductivity at zero time, $\sigma_{\mathrm{o}}$ the electrical conductivity at any time $\mathrm{t}$ and $\sigma_{\mathrm{o}}$ is the electrical conductivity at the end of saturation ( full crystallization). According to JMA equation the value of $\mathrm{n}$ can be obtained from the slopes of the plots of $\operatorname{Ln}[-\ln (1-\chi)]$ vs. Lnt are given in table (5) for the studied films a- $\mathrm{Si}_{0.47} \mathrm{Ge}_{0.53}: \mathrm{H}$, measured at $493,523,553$ and $573 \mathrm{~K}$. Since the volume fraction of the crystallized phases is assumed to depend on the conductivity of the material at any annealing time we found that the value of $\mathrm{n}$ does not depend on the composition and the annealing time as seen in table (5). The values of $\mathrm{k}$ according to JMA equation were obtained from the slopes of the plots of $-\ln (1-\chi)$ vs. $\left(\mathrm{t}^{\mathrm{n}}\right)$ and are given in table (5) for all films. 
According to equation (5) the values of the activation energies $E_{c}$ of crystallization deduced from the slopes of the plots of $\ln \mathrm{k}$ versus $1000 / \mathrm{T}$ for the $\mathrm{a}-\mathrm{Si}_{0.47} \mathrm{Ge}_{0.53}: \mathrm{H}$ are also given in table (5). It seen that the activation energy of crystallization depends on the substrate temperature.

Table (5): Values of $\mathrm{n}, \mathrm{k}$ and $\mathrm{E}_{\mathrm{c}}$ of $\mathrm{a}-\mathrm{Si}_{0.47} \mathrm{Ge}_{0.53}: \mathrm{H}$ thin films .

\begin{tabular}{|c|c|c|c|c|c|c|c|c|c|c|}
\hline \multirow{2}{*}{\multicolumn{2}{|c|}{$\begin{array}{l}\text { annealing } \\
\text { temperature } \\
\text { (T) }\end{array}$}} & \multicolumn{4}{|c|}{$\mathrm{n}$} & \multicolumn{4}{|c|}{$\mathrm{K}$} & \multirow{3}{*}{$\begin{array}{c}\mathrm{E}_{\mathrm{c}} \\
\mathrm{kJ} / \mathrm{mol}\end{array}$} \\
\hline & & \multirow[t]{2}{*}{$\begin{array}{l}493 \\
(\mathrm{~K})\end{array}$} & \multirow[t]{2}{*}{$\begin{array}{l}523 \\
(\mathrm{~K})\end{array}$} & \multirow[t]{2}{*}{$\begin{array}{c}553 \\
(\mathrm{~K})\end{array}$} & \multirow[t]{2}{*}{$\begin{array}{l}573 \\
(\mathrm{~K})\end{array}$} & \multirow[t]{2}{*}{$\begin{array}{l}493 \\
(\mathrm{~K})\end{array}$} & \multirow[t]{2}{*}{$\begin{array}{l}523 \\
(\mathrm{~K})\end{array}$} & \multirow[t]{2}{*}{$\begin{array}{l}553 \\
(\mathrm{~K})\end{array}$} & \multirow[t]{2}{*}{$\begin{array}{l}573 \\
(\mathrm{~K})\end{array}$} & \\
\hline samples & $\begin{array}{c}\mathrm{T}_{\mathrm{s}} \\
\left({ }^{\circ} \mathrm{C}\right)\end{array}$ & & & & & & & & & \\
\hline $\begin{array}{c}\mathrm{a}- \\
\text { SiGe:H }\end{array}$ & 200 & 1.09 & 1.19 & 1.28 & 1.37 & $5.79 \times 10^{-5}$ & $3.03 \times 10^{-4}$ & $\begin{array}{l}4.09 \\
\times 10^{-}\end{array}$ & $\underset{4}{6.45 \times 10^{-}}$ & 67.1 \\
\hline $\begin{array}{c}\mathrm{a}- \\
\text { SiGe:H }\end{array}$ & 250 & 0.796 & 0.774 & 0.627 & 0.671 & $0.563 \times 10^{-}$ & $0.716 \times 2 \times 10^{-}$ & $\begin{array}{l}2.01 \\
\times 10^{-} \\
2\end{array}$ & $\underset{2}{1.89 \times 10^{-}}$ & 41.24 \\
\hline
\end{tabular}

\section{CONCLUSIONS}

The substrate temperature and annealing play an important role for determining the optical absorptionedge and electrical conductivity of a-SiGe:H. The results showed considerable improvements for electrical toconductivity of $\mathrm{a}-\mathrm{Si}_{0.47} \mathrm{Ge}_{0.53}: \mathrm{H}$ by controlling the hydrogen content and hydrogen configuration upon annealing.

\section{Acknowledgements}

Thanks primarily due to Dr. W. Beyer who supported this work by providing the deposition and characterization facilities. Technical support by F. Pennartz and R. Schmitz and financial support by the International Bureau, Forschungszentrum Juelich and El-Menoufia University are gratefully acknowledged.

\section{REFERENCES}

[1] M. S. Abo Ghazala, Physica B 293, 132 (2000).[2] G. G. Pethuraja, R. E. Welser, A. K. Sood, C. Lee, N.J. Alexander, H. Efstathiadis,

[2] P. Haldar, J. L. Harvey, Mater. Scie. Appi. vol. 3, pp. 67 (2012).[3] K. W. Jobson, J. P. R. Wells, R. E. I. Schropp, D. A. Carder, P. J.

[3] Philips, J. I. Dijkhuis, Phys. Rev. vol. 873, pp. 155202 (2006).[4] S. Acco , D.L. Williamson, P.A. Stolk, F.W. Saris, M.J. van den Boogaard,

[4] W.C. Sinke, W.F. van der Weg, S. Roorda, P.C. Zalm, Phys. Rev. B 53, 4415(1996).

[5] M. Daouahi, K. Zellama, H. Bouchriha, P. Elkaïm, Eur Phys J AP10,185 (2000) R.J. Soukup, N.J. Ianno, S.A. Darveau, C.L. Exstrom, Sol Energy Mater Sol. Cells 87,87 (2005).

[6] Y. Bouizem, A. Belfedal, J.D. Sib , A. Kebab , L. Chahed, J Phys Condens Matter, 19,356215 (2007).

[7] A. A. Langford, M. L. Fleet, B. P. Nelson, W. A. Lanford,and N. Maley, Phys. Rev. B 45, 13367 (1992).

[8] [9] W. B. Pollard and G. Lucovsky, Phys. Rev. B 26, 3172 (1982).[10] N. Blayo and B Drevillon, J.Non Cryst.solids 137-138, 775 (1991).

[9] K. W. Jobson and J.P.R. Wells,R.E. I. Schropp,N.Q. Vinh,J.I. Dijkhuis, J. Appl.Phys. 103,013106 (2008).[12] W. Paul, D. K. Paul, B. Von Roe Dern, J. Blake, S. Oguz, Phys. Rev. Lett.46, 1016 (1981).

[10] W. Beyer and U. Zastrow: J. Non-Cryst. Solids 266-269, p. 206 (2000).

[11] P. Agarwal and S. C. Agarwal: Phil. Mag. B80, p. 1327 (2000) C.Frigeri, L. Nasi, M. Serén yi, A. Csik, Z. Erdélyi, and D. L. Beke, Solid State Phenomena Vols. 156-158, pp 325-330 (2010)

[12] C. Wang, D. Wuu, S. Lien, Y. Lin, C. Liu, C. Hsu, and C. Chen, International Journal of Photoenergy, Vol. 2012, p. 6 (2012).

[13] M. S. Abo-Ghazala, Phys. Status Solidi C 8, No. 11-12, 3099-3102 (2011).[18] Mursai, S. Amiruddin, I. Usman, T. Winata, Sukirno, and M. Barmawi, Asian

[14] [J.Energy Environ, Vol.5, Issue3, pp. 211-222 (2004). S. R. Elliot, J. Non-Cryst. Solids 182, 40 (1994).

[15] J. A. Augis, J. E. Bennett, J. Thermal Anal. 13, 283 (1978).[32] M.M. EL-Zaidia, A. Shafi, A.A.Ammar, M. AboGhazala, J. Mat. Sci. 22, 1618 (1987). Pradeep, N.S. SaxenaA. Kumar, Physica Scripta 54, 207 (1996). 